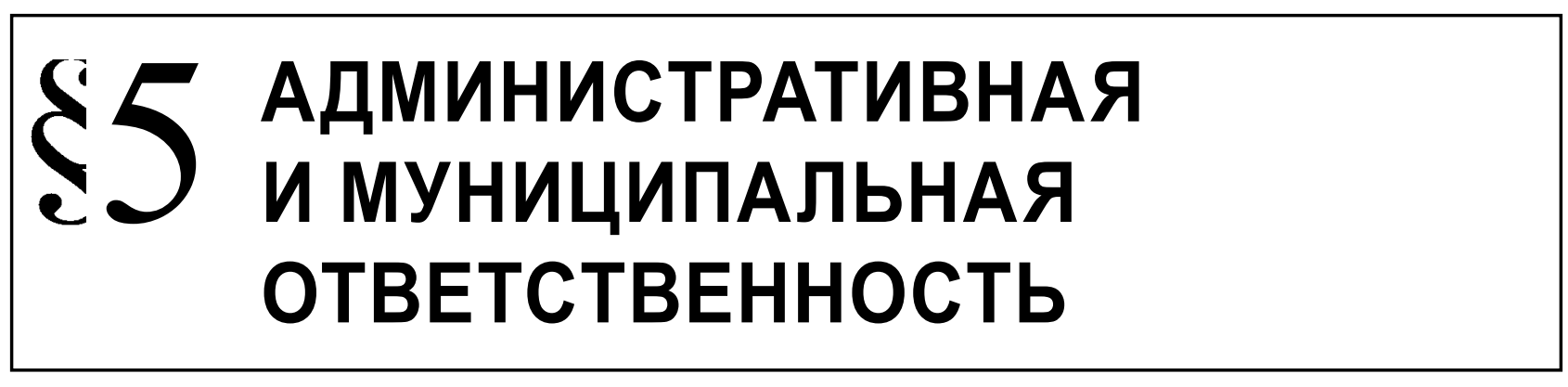

Паньшин Д.Л., Дресвянникова Е.А.

\title{
СРОКИ И ПОРЯДОК ИСПОЛНЕНИЯ ПОСТАНОВЛЕНИЙ ПО ДЕЛАМ ОБ АДМИНИСТРАТИВНЫХ ПРАВОНАРУШЕНИЯХ О ШТРАФАХ
}

\begin{abstract}
Аннотация: В современной административной правоприменительной практике исполнения постановлений о итрафрах принято считать, что существует шестьдесят дней для добровольной уплаты. Однако это не так.Поскольку при рассмотрении сроков исполнения постановления по делу об административном правонарушении, в статье нами обращается внимание на те периоды времени, когда, вопервых, лицо добровольно исполняет постановление, а во-вторых, когда должностное лицо приводит его в исполнение.По общему правилу, на основании части $1 \mathrm{cmaтьи} 32.2$ КоАП РФ предусмотрен шестидесятидневный срок в течении которого постановление по делу об административном правонарушении о наложении штрафа должно быть исполнено. То есть необходимо наличие документа подтверждающего уплату итрафа, а также информация о его уплате должна содержаться в информационных базах данных. При этом никто не принимает во внимание главу 31 КоАП РФ, где прямо предусмотрено, что постановление об административном правонарушении обязательно для исполнения с момента вступления в законную силу. Реализовать это должен судья, орган, должностное лицо вынесшее постановление, которое обязано обратить его к исполнению в течении трех дней путем направления уполномоченному должностному лицу приводить его в исполнение, что не в полной мере выполняется. Тем самым не реализуется принцип неотвратимости наказания.
\end{abstract}

Ключевые слова: исполнение, производство, отсрочка, рассрочка, сроки, административное, правонарушение, постановление, орган, управомоченный.

C ложившийся порядок исполнения постановлений по делам об административных правонарушениях не соответствует современным тенденциям развития исполнительской дисциплины и правовой культуры населения, поскольку не обеспечивает в полной мере реализацию принципа неотвратимости наказания. При рассмотрении сроков исполнения постановлений по делам об административных правонарушениях хотелось бы в данной статье обратить внимание на те периоды времени, когда, во-первых, лицо добровольно исполняет постановление, а во-вторых, когда должностное лицо обращает его к исполнению.

Правоприменительная практика государственных органов сводится к тому, что для исполнения постановлений по делам об административных правонарушениях применяется специальная норма Кодекса Российской Федерации об админи- стративных правонарушениях (далее - КоАП РФ), а именно статья 32.2 КоАП РФ. При этом в полной мере не реализуются положения, установленные общими нормами, регламентирующими исполнение постановлений по делам об административных правонарушениях (Глава 31 КоАП РФ).

Полагаем, что сроки и порядок обращения постановления по делу об административном правонарушении к исполнению и приведение в исполнение, предусмотренный статьей 32.2 КоАП РФ должен осуществляться через призму норм Главы 31 КоАП РФ, то есть при реализации обязанностей по исполнению постановлений, как должностными лицами, так и лицами привлеченными к административной ответственности, приоритет должен отдаваться, в первую очередь, применению норм Главы 31 КоАП РФ, регламентирующими общие положения исполнения постановлений, а уж 
затем применению специальных норм исполнения отдельных видов наказаний предусмотренных Главой 32 КоАП РФ.

По общему правилу, предусмотренного частью 1 статьи 31.9 КоАП РФ, установлен двухлетний срок, в течении которого постановление по делу об административном правонарушении может быть приведено в исполнение ${ }^{1}$.

Отмечаемые в средствах массовой информации данные о том, что срок и порядок добровольного исполнения постановления о назначении административного наказания в виде штрафа, лицом в отношении которого оно вынесено, определены в части 1 статьи 32.2 КоАП РФ, и составляет шестьдесят дней ${ }^{2}$.

Однако проведенный анализ части 1 статьи 32.2 КоАП РФ не дает нам возможности придти к выводу о шестидесятидневном сроке добровольного исполнения постановления, лицом в отношении которого оно вынесено. Поскольку, как указано, в выше приведенной норме, административный штраф должен быть уплачен лицом, привлеченным к административной ответственности, не позднее шестидесяти дней со дня вступления постановления о наложении административного штрафа в законную силу, либо со дня истечения срока отсрочки или рассрочки, предусмотренных статьей 31.5 КоАП РФ. Законодатель прямо указывает на обязанность не только лица, подвергнутого наказанию, исполнить постановление о наложении административного наказания, но и на обязанность должностного лица, вынесшего постановление, обратить его к исполнению не позднее шестидесяти дней.

Таким образом, авторами статьи усматривается иной порядок исполнения постановления по делу об административном правонарушении. Данный порядок коренным образом отличается от сложившейся правоприменительной практики, но является наиболее эффективным, так как в достаточной мере реализует принцип неотвратимости наказания.

При рассмотрении сроков и порядка исполнения постановлений необходимо обратить внима-

\footnotetext{
1 Кодекс Российской Федерации об административных правонарушениях от 30 декабря 2001 г. № 195-Ф3 (в ред. Федеральных законов РФ № 43-ФЗ от 5 апреля 2013 г.; № 49-ФЗ от 5 апреля 2013 г.; №98-ФЗ от 7 мая 2013 г.) // Собрание законодательства Российской Федерации. — 2002. — № 1 (часть I). Ст. 1.

2 Срок оплаты административных штрафов вырос до 60 дней // Электронный ресурс www.rg.ru/2013/05/09/shtrafisite.html (дата обращения 21 августа 2013 года).
}

ние на то, что в соответствии со статьей 31.2 КоАП РФ постановление по делу об административном правонарушении обязательно для исполнения всеми органами государственной власти, органами местного самоуправления, должностными лицами, гражданами и их объединениями, юридическими лицами, и подлежит исполнению с момента его вступления в законную силу.

Установленная обязательность исполнения постановления с момента вступления его в законную силу предполагает, что постановление должно быть исполнено всеми, в том числе и лицом в отношении которого оно вынесено, с момента вступления в законную силу вне зависимости от сроков обращения к исполнению или приведения в исполнение.

В свою очередь, в силучасти 1 статьи 31.3 КоАП РФ, у судьи, органа, должностного лица, вынесших постановление о назначении административного наказания, существует обязанность обратить постановление к исполнению.

Таким образом, постановление об административном правонарушении обязательно для исполнения с момента вступления его в законную силу, как лицом, в отношении которого оно вынесено, так и судьей, органом, должностным лицом его вынесшим.

Судья, орган и должностное лицо, вынесшие постановление о назначении наказания в виде административного штрафа должны стремиться к реализации принципа неотвратимости наказания и обязательности исполнения постановления в установленные сроки.

Так, на основании части 3 статьи 31.2 КоАП РФ судья, орган, должностное лицо вынесшее постановление по делу об административном правонарушении, в случае если постановление не было обжаловано или опротестовано в установленные сроки (часть 1 статьи 30.3 КоАП РФ), направляет его в орган, должностному лицу уполномоченным приводить его в исполнение, в течении трех суток со дня его вступления в законную силу, а в случае рассмотрения жалобы, протеста - со дня поступления решения по жалобе, протесту из суда или от должностного лица, вынесших решение.

Статьей 31.4 КоАП РФ установлено, что приведение в исполнение постановления по делу об административном правонарушении производится уполномоченным органом или должностным лицом, в порядке предусмотренном КоАП РФ и другими федеральными законами. 
В силу статьи 5 Федерального закона «Об исполнительном производстве» принудительное исполнение судебных актов, актов других органов и должностных лиц возлагается на Федеральную службу судебных приставов и ее территориальные органы ${ }^{3}$.

В соответствии с частью 7 статьи 21 Федерального закона «Об исполнительном производстве» в течение двух лет со дня вступления в законную силу, судебные акты, акты других органов и должностных лиц по делам об административных правонарушениях могут быть предъявлены к исполнению должностными лицами уполномоченными обращать постановление к исполнению.

Таким образом, у лица, привлеченного к административной ответственности и в отношении которого вступило в законную силу постановление по делу об административном правонарушении, есть трехдневный срок для добровольного исполнения постановления, а судья, орган, должностное лицо вынесшее постановление по делу об административном правонарушении в течение трех дней направляет его уполномоченному лицу приводить его в исполнение.

Совершенно очевидно, что при наличии определенных обстоятельств, а также с учетом материального положения, лицу привлеченному к административной ответственности и которому назначено наказание в виде штрафа, исполнение постановление может быть отсрочено или рассрочено (статья 31.5 КоАП РФ).

Для реализации права лица, привлеченного к административной ответственности, на отсрочку или рассрочку исполнения постановления, необходимо заявление лица в отношении которого оно вынесено и правоустанавливающий документ должностного лица вынесшего постановление. В противном случае отсрочка или рассрочка исполнения постановления не предоставляется, а постановление по делу об административном правонарушении обращается к исполнению в течение трех дней, так как оно, обязательно для исполнения (часть 2 статьи 31.1 КоАП РФ).

При исчислении срока давности исполнения постановления о назначении административного наказания, следует иметь в виду, что частями 24 статьи 31.9 КоАП РФ предусмотрены случаи, ког- да течение этого срока прерывается, либо приостанавливается.

Прерывание срока исполнения постановления предусмотрено частью 2 статьи 31.9 КоАП РФ, в случае, если лицо, привлеченное к административной ответственности, уклоняется от исполнения постановления о назначении административного наказания в течение двух лет со дня вступления постановления в законную силу.

Приостановление срока исполнения постановления о назначении административного наказания в соответствии с частью 1 статьи 31.6 КоАП РФ возможно в случае принесения протеста прокурором, либо, в силу части 1 статьи 31.5 КоАП РФ, когда исполнение постановления по делам об административных правонарушениях, предусматривающих наказание в виде штрафа, отсрочено на срок до одного месяца.

При наличии обстоятельств, вследствие которых исполнение постановления невозможно в установленные сроки с учетом материального положения лица, привлеченного к административной ответственности, уплата административного штрафа может быть рассрочена на срок до трех месяцев (часть 2 статьи 31.5 КоАП РФ).

Таким образом, обязанность лица, подвергнутого наказанию, исполнить постановление по делу об административном правонарушении о наложении административного штрафа возникает со дня вступления его в законную силу, и действует в течении шестидесяти дней, а в случае отсрочки или рассрочки, со дня их истечения. В случае отсутствия доказательства об уплате штрафа, а именно документа, свидетельствующего об его уплате, а также информации об этом в информационных базах данных, по истечении выше указанного шестидесятидневного срока, судья, орган, должностное лицо вынесшие постановление направляют его, как мы уже убедились выше, повторно в течение десяти суток судебному приставу-исполнителю для исполнения (часть 5 статьи 32.2 КоАП РФ). При этом судья, орган, должностное лицо вынесшие постановление по делу об административном правонарушении, в течении шестидесяти дней обращают его к исполнению, исходя из предоставленных им полномочий (глава 31 КоАП РФ).

\footnotetext{
3 Федеральный закон от 02 октября 2007 г. №229-Ф3 «Об исполнительном производстве» (в ред. Федерального закона от 5 апреля 2013 г. №49-Ф3) // Собрание законодательства Российской Федерации. - 2007. - №41. - Ст. 4849.
} 


\section{Библиография:}

1. Кодекс Российской Федерации об административныхправонарушениях от 30 декабря 2001 г. № 195-Ф3 (в ред. Федеральных законов РФ № 43-ФЗ от 5 апреля 2013 г.; № 49-ФЗ от 5 апреля 2013 г.; №98-ФЗ от 7 мая 2013 г.) // Собрание законодательства Российской Федерации. - 2002. - № 1 (часть I). — Ст. 1.

2. Постановление Пленума Верховного суда Российской Федерации от 24 марта 2005 г. № 5 «0 некоторых вопросах, возникающих у судов при применении Кодекса РФ об административных правонарушениях» // Российская газета. - 2005. - № 80. - 19 апр.

3. Федеральный закон от 02 октября 2007 г. №229-ФЗ «Об исполнительном производстве» (в ред. Федерального закона от 5 апреля 2013 г. №49-Ф3) // Собрание законодательства Российской Федерации. - 2007. — №41. - Ст. 4849.

4. Докучаева Т.В. Производство по жалобам об оспаривании постановлений органов, должностных лиц по делам об административных правонарушениях // LEX RUSSICA (РУССКИЙ ЗАКОН). - 2004. - 1. C. 202-217.

5. Приженникова А.Н. Состояние правового регулирования административного судопроизводства: пути решения. // NB: Административное право и практика администрирования. - 2013. - 5. C. 70-85. URL: http://www.e-notabene.ru/al/article_8739.html

6. Куракин А.В. Компетенция полиции в сфере реализации законодательства об административных правонарушениях // NB: Административное право и практика администрирования. - 2013. - 4. C. 28-48. URL: http://www.e-notabene.ru/al/article_8841.html

\section{References:}

1. Kodeks Rossiiskoi Federatsii ob administrativnykh pravonarusheniyakh ot 30 dekabrya 2001 g. № 195-FZ (v red. Federal'nykh zakonov RF № 43-FZ ot 5 aprelya 2013 g.; № 49-FZ ot 5 aprelya 2013 g.; №98-FZ ot 7 maya 2013 g.) // Sobranie zakonodatel'stva Rossiiskoi Federatsii. — 2002. — № 1 (chast' I). — St. 1.

2. Postanovlenie Plenuma Verkhovnogo suda Rossiiskoi Federatsii ot 24 marta 2005 g. №5 «0 nekotorykh voprosakh, voznikayushchikh u sudov pri primenenii Kodeksa RF ob administrativnykh pravonarusheniyakh» // Rossiiskaya gazeta. — 2005. — № 80. - 19 apr.

3. Federal'nyi zakon ot 02 oktyabrya 2007 g. №229-FZ «Ob ispolnitel'nom proizvodstve» (v red. Federal'nogo zakona ot 5 aprelya 2013 g. №49-FZ) // Sobranie zakonodatel'stva Rossiiskoi Federatsii. — 2007. — №41. — St. 4849.

4. Dokuchaeva T.V. Proizvodstvo po zhalobam ob osparivanii postanovlenii organov, dolzhnostnykh lits po delam ob administrativnykh pravonarusheniyakh // LEX RUSSICA (RUSSKII ZAKON). - 2004. — 1. S. 202-217.

5. Prizhennikova A.N. Sostoyanie pravovogo regulirovaniya administrativnogo sudoproizvodstva: puti resheniya. // NB: Administrativnoe pravo i praktika administrirovaniya. - 2013. - 5. - S. 70-85. URL: http://www.enotabene.ru/al/article_8739.html

6. Kurakin A.V. Kompetentsiya politsii $\mathrm{v}$ sfere realizatsii zakonodatel'stva ob administrativnykh pravonarusheniyakh // NB: Administrativnoe pravo i praktika administrirovaniya. - 2013. - 4. - S. 28-48. URL: http://www.e-notabene.ru/al/article_8841.html 